\title{
Antimicrobial activity of colostrum after administering killed Escherichia coli 0111 vaccine orally to expectant mothers
}

\author{
S DLUHOLUCKÝ, P SIRÁGY, P DOLEŽEL, J ŠVÁČ, AND A BOLGÁČ \\ Department of Microbiology and Hygiene, Department of Obstetrics and Gynaecology, and \\ Department of Paediatrics, Regional Hospital, Banská Bystrica, Czechoslovakia
}

SUMMARY An attempt was made to see if it was possible to produce antimicrobial activity in colostrum after killed Escherichia coli $\mathrm{O} 111$ vaccine had been given orally to expectant mothers. The colostral samples were used in vitro for the inhibition test immediately after the start of lactation. The colostrum from 7 of the 47 vaccine-treated mothers inhibited the growth of E.coli O111 compared with only one colostrum from 101 controls. No complication has occurred either in the vaccine-treated mothers or their suckling babies. The association between the presence of antimicrobial activity in the colostrum and the time of vaccine application was insignificant.

The protective role of breast milk against infections of newborn infants is well accepted..$^{1-3}$ The mammary gland is a potent immunological organ and produces active macrophages, lymphocytes, ${ }^{2}{ }^{4}$ and secretory immunoglobulin A (SIgA). This is resistant to acid degradation and to the action of proteolytic enzymes ${ }^{5}$ which make up almost half the protein content of the early colostrum. ${ }^{6}$ It is striking that human milk contains SIgA antibodies to many bacterial and viral antigens ${ }^{7}$; these antibodies are directed mainly against the mother's own gastrointestinal flora. It seems possible that lymphoid cells from the Peyer's patches, triggered antigenically, might home to mammary glands producing specific SIgA-antibodies. $^{7-8}$ In this way the mother produces in her milk specific SIgA antibodies against the bacteria in her intestine ${ }^{8}$ and her breast-fed baby who may be exposed to these bacteria is protected against them. This phenomenon 'homing' is an important protection for suckling infants against both enteric and systemic infections, and it would seem desirable to

\footnotetext{
Regional Hospital, Banská Bystrica

Department of Paediatrics

S DLUHOLUCKY, head of department

Department of Microbiology and Hygiene

P SIRÁGY

Department of Gynaecology and Obstetrics

P DOLEŽEL

A BOLGÁć

Methodological Centre

J ŠvÁc, head
}

develop a vaccine for women to give improved protection to their breast-fed babies. ${ }^{\text {? }}$

Lodinová et al. ${ }^{9}$ showed that artificial culonisation of the infant induces the specific antibody response in both serum and stool (coproantibodies). Using Escherichia coli 083 , Goldblum et al. ${ }^{8}$ found that within a few days after intestinal colonisation with $E$. coli $\mathrm{O} 83$, three pregnant women had lymphoid cells producing $\mathrm{SIgA}$ antibodies to the $\mathbf{0 8 3}$ antigen in their milk.

Our study was undertaken in an attempt to produce a colostral antibacterial response after killed E. coli 0111 vaccine had been given orally to the expectant mother.

\section{Materials and methods}

The study was made between 1 January and 30 November 1978 and comprised 148 expectant mothers. 47 of them had been vaccinated, and 101 served as controls, the women being selected randomly. The expectant mothers were those admitted at term. Some of them were in labour and others were awaiting its onset. Thus some mothers received vaccine for only 1 day and others for up to 15 days before they started to lactate and to produce colostrum. In both vaccinated and control groups the stool samples for isolation of enteropathogenic $E$. coli were obtained immediately after admission to hospital. Stool-positive mothers were excluded 
from the study. Women in the treated group were given $E$. coli 0111 vaccine $1 \mathrm{ml}$ three times daily before meals by mouth from the time of their admission to the time that lactation began. After the start of lactation the colostrum was sampled by manual expression and taken immediately to the department of microbiology. Colostrum samples were similarly obtained from the untreated group. No mother from either group received any antibiotic or drug that was likely to have antimicrobial activity.

Preparation of vaccine. Three different strains of $E$. coli 0111 were used: two had been isolated from hospital patients and one came from a microbiological collection of strains. After 24 hours of incubation the strains were washed off with saline and diluted after McFarland ${ }^{10}$ to give a suspension density of approximately $10^{9}$ bacteria per $\mathrm{ml}$. Inactivation was carried out in an Arnold apparatus at $115^{\circ} \mathrm{C}$ for 120 minutes. Tests of sterility and toxicity performed in vitro and on mice and guineapigs were negative. The safety of the vaccine was tested by volunteers from the paediatric staff, who developed no symptoms within 2 days of taking the vaccine.

The inhibitory activity of colostrum was investigated by an agar-diffusion test against homologous E. coli O111 strains. Holes $6 \mathrm{~mm}$ in diameter in the agar plate were filled with $0.1 \mathrm{ml}$ colostrum, and the inhibition zone of bacterial growth was evaluated after 24 hours of incubation. Inhibition extending more than $6 \mathrm{~mm}$ (the diameter of hole) was accepted as being positive (Figure).

Most of the vaccine-treated mothers tolerated the vaccine well. The only two exceptions vomited after ingestion and were excluded from the study.

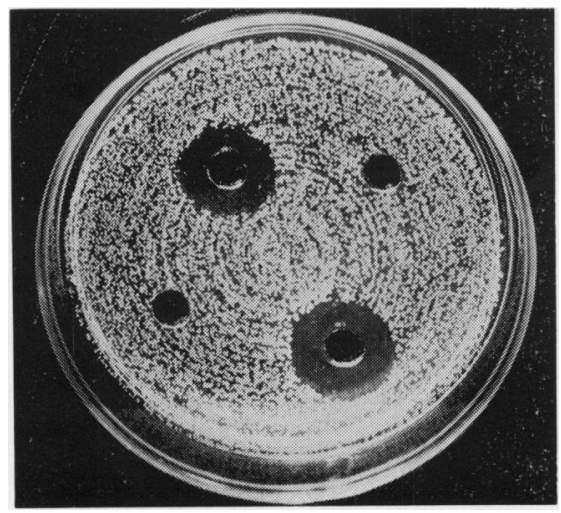

Figure Inhibition of Escherichia coli 0111 growth on agar by colostrum of vaccine-treated mothers compared with control colostrum.
Table 1 Antibacterial activity of colostrum after Escherichia coli 0111 vaccination

\begin{tabular}{llll}
\hline Group & \multicolumn{3}{l}{ Positive } \\
\cline { 2 - 4 } & No. & $(\%)$ & $P$ \\
\hline $\begin{array}{l}\text { Vaccine-treated } \\
(\mathrm{n}=47)\end{array}$ & 7 & 15 & $<0.001$ \\
$\begin{array}{l}\text { Control } \\
(\mathrm{n}=101)\end{array}$ & 1 & 1 & \\
\hline
\end{tabular}

Table 2 Antimicrobial activity of vaccine-treated group in relation to the time of vaccine application before onset of lactation

\begin{tabular}{|c|c|c|c|c|c|}
\hline \multirow{3}{*}{$\begin{array}{l}\text { No. of days } \\
\text { vaccine given }\end{array}$} & \multirow{3}{*}{$\begin{array}{l}\text { No. of } \\
\text { cases } \\
(n=47)\end{array}$} & \multicolumn{4}{|c|}{ Inhibitory activity } \\
\hline & & \multicolumn{2}{|c|}{ Positive $(n=7)$} & \multicolumn{2}{|c|}{ Negative $(n=40)$} \\
\hline & & No. & $(\%)$ & No. & $(\%)$ \\
\hline $\begin{array}{r}1-6 \\
7-12 \\
13-15\end{array}$ & $\begin{array}{r}16 \\
24 \\
7\end{array}$ & $\begin{array}{l}1 \\
6 \\
0\end{array}$ & $\begin{array}{r}(6) \\
(25)\end{array}$ & $\begin{array}{r}15 \\
18 \\
7\end{array}$ & $\begin{array}{r}(94) \\
(75) \\
(100)\end{array}$ \\
\hline
\end{tabular}

We tried to find out if the colostrum of treated mothers had more antimicrobial activity in vitro than that of the controls. We also tried to find out how long the vaccine should be given to obtain the best effect.

Results

The antimicrobial activity of colostrum after vaccination is shown in Table 1 . Colostrum was obtained from 47 vaccine-treated mothers, 7 of whom had antimicrobial activity in their colostrum. In the 101 controls only one sample was positive. The difference is highly significant $(P<0 \cdot 001)$.

In the group of treated mothers we attempted to relate the number of 'positive reacting' mothers to the time of vaccination before lactation. At first sight (Table 2) the percentage of 'positive mothers' appears to depend on the time of vaccination although statistical significance is not attained ( $\chi^{2}$ test and one factor analysis of variance), probably due to the small numbers.

\section{Discussion}

Previous studies have shown that a transient intestinal colonisation of women during pregnancy with $E$. coli ${ }^{8}$ and Salmonella typhimurium ${ }^{11}$ will selectively induce a specific IgA response in colostrum. Although oral immunisation could clearly be of value for the enhancement of the passive immune protection transferred to the suckling neonate via mammary secretions, there are obvious problems associated with the use of live oral vaccines. 
The results of the present study however, indicate that oral application of a heat-killed $E$. coli vaccine can also induce antibacterial activity in colostrum. Since we have not investigated the specificity of this activity we cannot rule out the possibility that it is mediated by one or more of the nonspecific antimicrobial components contained in mammary secretions. ${ }^{12}$ We hope that further studies will help to determine the mechanism of the antibacterial activity and show what influence the antigen dose has on the development of the local response.

\section{References}

1 Gerrard J W. Breast feeding. Second thoughts. Pediatrics $1974 ; 54$ : 757-64.

2 Head J R. Immunobiology of lactation. Semin Perinatol 1977; 1 : 195-210.

3 Miler I. Imunologický význam kojení (in Czechoslovakian). Praktický Lékä̈ 1978; 58: 249-53.

4 Pitt J. Breast milk leukocytes. Commentaries. Pediatrics 1976; 58: 769-70.

5 Tomasi T B, Bienenstock J. Secretory immunoglobulins. Adv Immunol 1968; 9: 1-96.

- Hanson L A. Comparative immunological studies of the immune globulins of human milk and of blood serum. Int Arch Allergy Appl Immunol 1961 ; 18: 241-67.

7 Hanson L $\AA$. Esch. coli infections in childhood. Arch Dis Child 1976; 51: 737-43.

8 Goldblum R M, Ahlstedt S, Carlsson B, et al. Antibodyforming cells in human colostrum after oral immunisation. Nature 1975; 257 : 797-9.

๑ Lodinová R, Jouja V, Wagner V. Serum immunoglobulins and coproantibody formation in infants after artificial intestinal colonization with Escherichia coli 083 and oral lysosyme administration. Pediatr Res 1973; 7: 659-99.

10 Sedlák J, Rische H. Enterobakteriaceae-Infekcionen. Leipzig: Thieme, 1968.

11 Allardyce R A, Shearman D J C, McClelland D B L Marwick K, Simpson A J, Laidlaw R B. Appearance of specific colostrum antibodies after clinical infection with Salmonella typhimurium. Br Med J 1974; iii : 307-9.

12 Welsh J K, May J T. Anti-infective properties of breast milk. J Pediatr 1979; 94: 1-9.

Correspondence to Dr S Dluholucký, Department of Paediatrics, Regional Hospital, 97517 Banská Bystrica, Czechoslovakia.

Received 22 May 1979 